\title{
The social economy of rhino poaching: Of economic freedom fighters, professional hunters and marginalized local people
}

\section{Annette M Hübschle}

Environmental Security Observatory, University of Cape Town, South Africa

\begin{abstract}
In light of the high incidence of rhino poaching in southern Africa, the African rhinoceros might become extinct in the wild in the near future. Scholars from a variety of disciplines have analysed drivers of illegal hunting and poaching behaviour in general terms. Existing scholarship on rhino poaching proffers a simplistic concurrence of interlinked drivers, including the entry of transnational organized crime into wildlife crime, opportunity structures and the endemic poverty facing people living close to protected areas. By engaging with the lived experiences and social worlds of poachers and rural communities, this article reflects on empirical evidence gathered during ethnographic fieldwork with poachers, prisoners and local people living near the Kruger National Park. It is argued that the socio-political and historical context and continued marginalization of local people are significant factors facilitating poaching decisions at the grassroots level. Green land grabs and the systematic exclusion of local people from protected areas, as well as the growing securitization of anti-poaching responses, are aiding the perception that the wild animal is valued more highly than black rural lives. As a consequence, conservationists and law enforcers are viewed with disdain and struggle to obtain cooperation. The article critiques the current fortress conservation paradigm, which assumes conflict-laden relationships between local people and wildife.
\end{abstract}

\section{Keywords}

Anti-poaching, drivers of poaching, fortress conservation, green land grabs, illegal hunting, local communities, protected areas, rhino poaching, securitization

\section{Corresponding author:}

Annette M Hübschle, Environmental Security Observatory, University of Cape Town, Rondebosch, 770I, South Africa.

Email: annette.hubschle@uct.ac.za 


\section{Introduction}

Close to 6000 rhinoceroses have been illegally hunted in South Africa since 2008 (Molewa, 2016). South Africa is home to $79 \%$ of world's remaining rhinos, with the Kruger National Park (hereafter KNP) hosting half of the country's rhino populations. Poachers are after the wild animal's horn, one of the most expensive goods in the world. ${ }^{1}$ Besides being coveted as an ingredient in Traditional Asian Medicines (TAM), rhino horn has been elevated to a status symbol by wealthy consumers in Asian markets, who display their affluence through conspicuous consumption of luxury goods, including rare rhino horn. Horn is also used as an investment instrument, criminal currency, or as a gift to cement business relations. An arsenal of protective measures has achieved limited success in disrupting illicit flows of rhino horn from the bush to the market. Although a diverse set of actors is involved along the length of the rhino horn supply chain, the role and motivations of rhino poachers need further unpacking if we are to understand the push-and-pull factors underpinning the illegal rhino horn economy.

The poaching of endangered or threatened species is not a new phenomenon, but scholarly interest has focused on economic, thrill-seeking and opportunistic theories of poaching in the past (see for example Forsyth and Marckese, 1993; Muth and Bowe, 1998). Due to the assumed linkages to species extinction, growing incidents of humanwildlife conflict and awareness raising campaigns by environmentalists, there has been renewed interest in theories of poaching. Scholars from a variety of disciplines, including criminology, economics, anthropology, sociology, security studies, human geography and international relations, have researched drivers of poaching behaviour, profiled the offenders, and categorized the crime (von Essen et al., 2014: 7). In studying the drivers of poaching behaviour, many scholars' fall-back position are 'cooking pot and pocket book' motivations (Kahler and Gore, 2012). However, a new stream of scholars has started to explore the socio-political context (Fischer et al., 2013), cultural explanations (Bell et al., 2007) and the institutional setting (Kahler and Gore, 2012) to explain poaching decisions. Within the rhino field, the entry of transnational organized crime, growing demand in consumer markets and the endemic poverty of people living close to protected areas are proffered as leading and interlinked drivers of rhino poaching (see for example Milliken, 2014; Montesh, 2013). Many rhino poachers originate in communities living close to or in protected areas; in other cases, poachers receive protection, services or assistance from people living close to protected areas. Moreover, local people fear law enforcement and parks officials who they believe to be either corrupt or untrustworthy. ${ }^{2}$ The relationship of local people and parks in the South African context is complex due to historical, social and political factors, which remain largely unacknowledged in the extant literature. Moreover, the underlying assumption that poverty leads to deviance, in this case, rhino poaching, has long been questioned in sociological and criminological research (Hirschi, 1973; Merton, 1938) and is further unpacked in this article. The lack of an engagement with the historical context of land expropriation, loss of hunting and other land use rights, as well as the forced removals during the colonial and apartheid regimes, constitutes a gap in the literature on rhino poaching. This article advances the idea that the socio-political and historical context and continued marginalization are significant factors leading to poaching decisions at the grassroots level. Poaching should 
thus be seen as a form of social and political protest. It is further argued that the current disruptive regime in the form of 'the war on poaching' and the displacement of communities from parks and buffer zones contribute to the social reproduction of historical inequalities, stigmatization and alienation of communities, who, under different circumstances and framing, might be agents of change and disruptors of illegal horn supplies. The article documents the lived experiences and social worlds of poachers, traffickers and local people by drawing on empirical evidence gathered during ethnographic fieldwork in communities, protected areas and prisons.

The article starts with a description of methods and the research sites and a review of the relevant literature on poaching. The following sections sketch the historical context of nature conservation in colonial and apartheid South Africa before turning to transfrontier conservation. After that the focus shifts to the community level through an examination of the pathways to poaching and the social economy of rhino poaching, as well as the impact of anti-poaching responses on local people.

\section{Methods and research sites}

The research for this article emanates from a multi-sited ethnography (cf. Hübschle, 2016) in which I used a follow-the-thing approach (Appadurai, 1988; Foster, 2006) by tracing the social relations and structures underpinning the movement of rhino horn from the southern African bush to south-eastern Asian markets. More than 420 research informants participated in interviews and focus groups during 14 months of fieldwork in 2012 and 2013, and follow-up visits were conducted in 2015 and 2016. The sample included, among others, convicted and active rhino poachers, kingpins, smugglers, organized crime investigators, private anti-poaching operatives and state security forces, as well as affected local communities. While the research project explored actors and their social relations along the entire supply chain, this article hones in on rhino poachers who hunt rhinos in the protected areas of South Africa. Regulatory responses are largely devoted to this group of criminals, who are regarded as the foot soldiers of transnational organized crime networks (Milliken, 2014). It is acknowledged that rogue elements in the wildlife industry are key actors in the transnational supply chain and their role is discussed elsewhere (Hübschle, 2016). It is hoped that this article contributes to a nuanced understanding why not only rhino criminals but also local people may be unfavourably inclined towards the current rhino protection regime.

The geographic focus of this article is the KNP, South Africa's signature national park, the Limpopo National Park (hereafter LNP) and communities living in or beyond the Parks' borders. The KNP is home to the greatest number of rhinos in the world (about $40 \%) .{ }^{3}$ Roughly the same size as Wales, the KNP stretches across an area of close to $20,000 \mathrm{~km}^{2}$. The Park extends $350 \mathrm{~km}$ from north to south and shares international borders with Zimbabwe and Mozambique. At the time of the initial fieldwork in 2013 and $2014,70 \%$ of rhino poachers were believed to enter the KNP from Mozambique. This scenario had changed at the time of writing the article in 2016 with most rhino poachers commencing their hunting expeditions along the western boundary - the majority are still believed to originate from local communities living near the Park - or from within the Park (posing as tourists or KNP staff) in South Africa. Park officials assume that the 
geographic displacement is a response to increased law enforcement activities close to the Mozambican border.

\section{Pathways to poaching}

Scholars face several dilemmas when writing about poachers and the act of poaching. The distinction between poaching and hunting, for example, is riddled with normative claims about moral and legal boundaries. Poaching is defined as 'the illegal shooting, trapping or taking of game or fish from private or public property' (West's Encyclopedia of American Law, 2008), whereas hunting is socially and legally sanctioned in many jurisdictions. The definition of poaching refers to property rights, which are frequently contested when it comes to protected areas and private land in the Global South. Changes in legal definitions may render a formerly legal activity, such as subsistence hunting or the collection of medicinal plants, a criminal act (Comaroff and Comaroff, 2006). Such legal changes may undermine cultural practices and survival strategies of First Nations peoples, as evidenced in Botswana, where security forces are clamping down on the San peoples who hunt on their ancestral lands to feed their families. While this form of subsistence hunting is forbidden and branded as poaching, trophy hunters are still allowed to hunt big game on private land in Botswana (Survival International, 2016). The racebased normative categorization of black poacher versus white hunter is of significance in the African context (cf. Beinart, 2003). Wealthy (usually white) trophy hunters may hunt wild animals against a fee in some states (hunting profits are ostensibly employed to serve conservation objectives) while 'locals with limited resources are stigmatized as poachers when trespassing and hunting wild animals on land that was formerly theirs' (Hübschle, 2016: 362). In his game-changing article, Neumann (2004) showed how African poachers were dehumanized in the popular media to allow for the normalization of shoot-on-sight orders in African conservation areas where methods of war have become an acceptable conservation strategy. This stream of scholars points to the importance of engaging with the history of conservation practices, protected areas and local communities, when studying wildlife crime.

Criminologists and policy researchers have set the tone in the literature on drivers of rhino poaching by examining opportunity structures (Eloff and Lemieux, 2014; Herbig and Warchol, 2011), endemic poverty ${ }^{4}$ and anger of communities (Fenio, 2014), weak governance, corruption and the entry of transnational organized crime (Montesh, 2013; Rademeyer, 2016a, 2016b). Beyond a few exceptions (see for example Duffy and St John, 2013; Fenio, 2014), researchers pay limited attention to structural and historical drivers, the social setting and institutional milieu. Fenio (2014:2) facilitated focus groups in what she referred to as 'poaching communities'. She found that community members were angry at conservation authorities because of limited employment, opportunities and profit trickling down and high levels of human-wildlife conflict. Duffy and St John (2013: 4) argue that poaching 'was produced via the historical legacy of colonialism' in most of Africa. The researchers acknowledge the need for a better understanding of the relationships between individual poacher motivations and poverty. Problematic in much of the literature is the unexplained assumption that poverty breeds rhino poaching. Sociologists and criminologists have refuted claims that poor people are more prone to 
deviant behaviour (see for example Hirschi, 1973; Merton, 1938; Stark, 1987), which rings particularly true in the illicit rhino horn economy where wealthy individuals associated with the wildlife industry are heading rhino horn trafficking networks (cf. Hübschle, 2016; Rademeyer, 2012, 2016b).

Poaching research beyond the narrow rhino field offers further insights. For instance, Kahler and Gore (2012) undertook a study on the reasons why communities uphold wildlife laws in Namibia. The pair identified several poaching motivations that extend beyond what they termed 'cooking pot and pocket book' explanations for poaching behaviour. Several poachers were, for example, motivated by disagreements with the rules, linked to negative sentiments towards the establishment, governance or benefits distribution system of community conservancies in Namibia (Kahler and Gore, 2012: 115). ${ }^{5}$ These results resonate with research from North America, where Filteau (2012) found that the interaction between game wardens and poachers was an important determinant of voluntary compliance with conservation rules. An under-researched aspect of the literature is thus how changes in the rules, the racist and classist biases regarding hunting rights and violent enforcement strategies may lead to poaching decisions among those most adversely affected. Von Essen et al. (2014: 1) also point to this lacuna by arguing that the existing theories on drivers of poaching ignore the socio-political dimensions 'that render a number of hunting crimes difficult to explain by use of economic and opportunist models of behaviour' (von Essen et al., 2014: 14-15). Instead of stigmatizing poachers as criminals, the scholars propose a systematic examination of the socio-political context that may lead to illegal hunting (von Essen et al., 2014: 14), which the remainder of this article does.

\section{A brief historical context to nature conservation in southern Africa}

The history of nature conservation and the creation of parks in southern Africa are deeply intertwined with the colonial project and systematic exploitation of African peoples. Early conservation measures served the colonial objectives of state building and economic capture (cf. Carruthers, 1993, 1995); later measures were driven by the desire to preserve wildlife for sports hunting. At the turn of the 19th century, game reserves were designed to provide 'free from all human interference, a sanctuary in which certain species of wildlife could prosper' (Carruthers, 1993: 13). Indigenous property and hunting rights and ancestral burial grounds (which are significant cultural sites) were not considered when protected areas were declared. Colonial authorities professed, for example, that the KNP was proclaimed on terra nullius (uninhabited land) (Meskell, 2012); however, the numerous land claims lodged during the Land Claims process in post-apartheid South Africa provide evidence to the contrary (Diale, 2016). With the advent of the formalized system of apartheid in South Africa in 1948, African people experienced 'double exclusion' from national parks: they were denied visitor's access to the parks, and systematically excluded from the governance of parks (Cock and Fig, 2000: 132). Parks such as the KNP came to represent a mechanism of apartheid rule. So-called 'fortress conservation' 6 served the political elite during the colonial and apartheid regimes, as it brought large areas of land into direct control of the state and led to the eviction of local people. 
Similar processes played out in Mozambique. The country was haunted by the decadelong civil war, which ended in 1992. The civil war did not only lead to the displacement of people but also to the loss of cattle and wildlife. In the area of the former Coutada 16 (now the LNP), no wildlife was left after the war (for more details see Lunstrum, 2010; Ramutsindela, 2006).

Transfrontier conservation has emerged as the new conservation approach in the postcolonial period. Transboundary conservation areas stretch beyond the artificial confines of political boundaries, thus allowing the protection of a transfrontier ecosystem in its entirety, rather than stopping at the border (Büscher, 2010). Couched in the discourse of social development and sustainable use (Munthali, 2007; Ramutsindela, 2007), transfrontier conservation is presented as the panacea to preserving and enlarging protected areas while also contributing to rural development (Kruger National Park, 2015; Peace Parks Foundation, 2014). The increasing privatization of conservation management and areas, as well as the significant role of non-state actors, such as conservation NGOs and corporations, reify the new approach (Lunstrum, 2013; Massé and Lunstrum, 2015). A school of researchers (Duffy, 2001; Singh and van Houtum, 2002; Spierenburg, 2011; Spierenburg et al., 2006) argue that transfrontier conservation follows the path dependency of the fortress conservation paradigm. Munthali (2007: 52), for example, observes:

Through their emphasis on state ownership and control, Transfrontier Parks are no different in principle from other national parks, where local communities are usually marginalised into buffer zones, and peripheral economic activities such as menial jobs as cooks, labourers, or guards.

While community beneficiation and participation are deemed important, promoters and implementers prefer local communities to live outside the protected areas. There is little doubt that the proclamation of large tracts of land as transnational conservation areas would have severe economic, social and cultural consequences for local people living inside or on the edge of these transfrontier parks. The establishment of the LNP is a good example of the tension between local communities and protected areas.

When the LNP was proclaimed as a total protection zone in 2001, around 27,000 people and their cattle were residing in the area (Milgroom and Spierenburg, 2008). These village communities ${ }^{7}$ had been affected by displacement during the colonial period and the Mozambican civil war. In preparation for the proclamation of the Park, the land use rights of Coutada 16 were changed from a multi-use conservation area to a 'total protection zone' (Lunstrum, 2013). The Mozambican Land Act of 1997 determines that no economic activity, resource use or occupation is allowed in 'total protection zones' (Tanner, 2002: 36-37). International experts recommended that the new conservation area would be more attractive to tourist operators if the villages were resettled (Spierenburg, 2011: 85-86; Interviews, 2013, 2014). Thus, 7000 people living in eight villages along the Shingwedzi River inside the Park were asked to move to assigned areas outside the park. A dispute ensued between the Mozambican Ministry of Tourism and the concerned villagers over whether they belonged in the park and what their rights were (Spierenburg et al., 2006: 94). The state won the dispute. As a consequence of the changed conservation status of the area, these 7000 people would have to 
relocate 'to make space for wild animals' that were to be reintroduced from the KNP (Spierenburg, 2013).

The German Development Bank ${ }^{8}$ stipulated that all relocations would have to happen on a voluntary basis (Milgroom and Spierenburg, 2008: 437). Milgroom and Spierenburg (2008: 437) found that many residents of the LNP 'began to feel the effects of economic displacement soon after the park was established in 2001, through the application of new park regulations prohibiting hunting and restricting extraction of forest products for commercial purposes'. Food security was greatly reduced as cultivation inside the Park was forbidden unless the area was used for farming prior to the declaration of the Park, ${ }^{9}$ access to emergency pastures for cattle in the Park during times of drought was forbidden and the reintroduction of predators affected both crops and cattle (Spierenburg, quoted in Arets et al., 2011: 58). Due to the reduced income opportunities and increasing outside pressure, villagers started to accept the relocation packages soon after the Park's inception. While the stated objective of the resettlement policy was to enable community empowerment and social development, the transition process has been less than smooth, and the resettlement from acceptance to relocation has been slow (for a detailed discussion of the protracted process of relocation, see Lunstrum, 2015). A significant oversight was inadequate consultation with communities directly affected by the establishment of the new park (Munthali, 2007). In the eyes of village communities who are or were resident in the Park, the formation of the LNP is associated with human-wildlife conflict (see for example Massé, 2016), impoverishment, as well as widespread contempt for conservation initiatives and the 'Big Brother' next door - the management and conservation staff of the KNP (Interviews with convicted poachers, 2013). The omission has not only led to rising levels of unhappiness among these communities, but also contributed to the perceived legitimacy of rule-breaking, including rhino poaching.

\section{Green land grabs: How the sins of the past and present affect rhino poaching}

When asked whether the rhino carried cultural significance or symbolic value, poachers observed that the rhino was 'feared', 'admired' and 'respected' but it was not customary to hunt the wild animal. For example, children are warned to stay clear of the rhino because it was an 'angry' and 'dangerous' animal. Why is the rhino hunted in spite of the reverence and respectful admiration? The most obvious answer would be the high price tag paid at the source and rising demand for rhino horn in consumer markets. One convicted poacher (Interview with poacher 16, SA correctional centre, 2013) made a significant observation in this regard:

You know I wasn't born to hunt a rhino. In the village, we hunt the small animals. You know the guys in the villages; they don't hunt the big animals. They want fresh meat. They only hunt for the day. Normally, they keep big animals safe. There is no fridge. And the land used to be free long ago, now the land is not free. I can't just go anywhere; otherwise the guy will start fighting with me. And he will say this is my land and we will start fighting. Government can stop this thing; they just must give people jobs. Crime is everywhere and the police is shooting us all. 
The rhino has a bounty on its horn that far outweighs the average annual income of rural communities along the western (South African) and eastern (Mozambican) boundary of the KNP. However, poaching and the shielding of poachers should be understood in the context of historical marginalization of rural communities and their continued sense of alienation. Poachers and community members cited the loss of their land, hunting and land use rights as triggers for dissent and drivers of poaching behaviour. An old woman who had been recently relocated from the LNP explains:

We were happy where we come from. There's no peace here, no hope. They can give you a house and the next day, they can remove it from you, and give it to someone else. We don't have a school here, no fields to grow our own food, and the youths are struggling to get jobs in this village. The youths do nothing. Some end up stealing because of the lack of jobs, others do rhino poaching. Some come back, some die, and some get arrested.

A rhino kingpin ${ }^{10}$ operating from a village in the LNP explained that the villages inside the Park were not only springboards for poaching excursions into Kruger, but that they had also become effective recruiting grounds for poaching expeditions. As mentioned in the previous section, the relocation of villagers has been a disjointed and protracted process. Due to diminished food security, ${ }^{11}$ increasing human-wildlife conflict and social fragmentation at the village level (for detailed accounts of the impact of transfrontier conservation on communities, see Büscher, 2010; Ramutsindela, 2007; Spierenburg, 2013; Spierenburg and Wels, 2006), many villagers are seeking voluntary and speedy relocation to minimize the disruption to their personal lives and livelihoods. However, political and economic processes, as well as financial austerity, are delaying the relocation of some of the remaining villages (Lunstrum, 2015; Interview with PPF representative, 2013; Interview with poaching kingpin, 2013). Mozambican government authorities have repurposed the land initially set aside for relocation and given it to a private investor for a sugarcane and ethanol plantation (Lunstrum, 2015). According to the South African Minister of Environmental Affairs (Molewa, 2016), the resettlement of communities should be complete by the end of 2017. At the beginning of 2016, villagers residing in the village of Massingir Velho (10 km from the international border) were moved 75 $\mathrm{km}$ away from the border as a measure to curb rhino poaching (eNCA, 2016).

Displacement and dispossession have emerged as causal factors, motivating men to become involved in poaching, and likewise motivating communities to shield perpetrators from law enforcement responses. A kingpin and his personal assistant observed the following (Group discussion, Massingir, 2013):

Because the people are still staying in the Park, they are angry. It increases rhino poaching. The people have agreed to be moved. There is just no money and land to relocate them ... Sometimes when they [park rangers] find a person walking in the Park, then they say they are visiting their relatives in the Park, even if they are there for illegal hunting ... If they [government] remove them, it will reduce the poaching but it will not stop it.

Meanwhile, private concession holders located along the length of the Mozambican border with the Kruger are seeing their land tenure rights protected (which had been tenuous) as their concessions have been declared as buffer zones in the name of protecting 
rhinos. ${ }^{12}$ According to a rezoning briefing document (SANParks, 2012: 4-5), the Great Lebombo Conservancy is to become 'the first shield of defence against rhino poaching, provide ecotourism development opportunities (on the Mozambican side) for the private sector investors and create a logical deterrent to poaching activities through tourism activities'. Mozambican state officials together with private concession holders have been seeking to integrate the patchy stretch of private concessions and state and communal lands into 'a unitary integrated conservancy/buffer zone' (Massé and Lunstrum, 2015: 6). New conservancies are granted to investors in order to 'fill in the gaps' where none previously existed, and other land uses were present. As a result, local communities have to move from these 'gaps' while access to resources will be restricted (Massé and Lunstrum, 2015). An intelligence actor observed the following (Interview with intelligence operative 8, 2013):

You might be moving potential poachers further away from the Park but where there is a will, there is a way. You have basically just added another $40 \mathrm{~km}$ for them to walk extra and that they will, and you have made some villagers very angry.

Focus groups with community members echoed widespread sentiments of marginalization and anger. Mozambican villagers, rangers, poachers and kingpins, as well as convicted rhino criminals serving prison sentences in South African correctional centres, expressed their annoyance with the state for valuing animals over black lives (Interviews and focus groups, 2012, 2013, 2015). A horn smuggler (Interview with intermediary 1, 2013) surmised:

This [rhino problem] is because of conservation. They say that we need those things [rhinos]. They are nice. Some of the white people here treat them like their friends. They value the rhino more than black human beings. And now they see it as a business, if you have two rhinos you are rich.

The notion that parks and foreign tourists trump the interests of rural communities was a recurring theme in interviews and focus groups in South Africa and Mozambique. The importance attributed to the 'white' rhino has taken on a symbolic meaning to some communities, whose concerns over land restitution, land use rights and livelihood strategies appear to have been moved off or down the state's agenda to protecting a wild animal instead (Focus groups and interviews, 2013, 2015).

Some community members felt strongly about the lack of bottom-up negotiation when it came to resolving the sins of the past and present, including land rights, resettlement, beneficiation and socio-economic development initiatives. Of importance here is also the question of who negotiates or speaks on behalf of the community. Conflicts have arisen over inequitable income distribution of beneficiation initiatives (see also Kahler and Gore, 2012). Local political elites in the form of traditional leaders, chiefs, headmen and sub-headmen often act as intermediaries, negotiating political, economic and social issues and traditional affairs between outside parties and communities in rural southern Africa (Ntonzima and Bayat, 2012). Community members remarked: 'If you are on the wrong side of the chief, then you will see no money or benefits' (Focus group with community members, 2013). The role and function of traditional leaders remain somewhat 
contested in post-apartheid South Africa as the system of indirect rule served both colonial and apartheid rule (cf. Beall and Ngonyama, 2009; Mamdani, 1996). Feelings of anger, disempowerment and marginalization tie in with the frequent occurrence of service-delivery protests ${ }^{13}$ in the semi-urban and rural areas along the south-western boundary of the KNP in South Africa. A South African poacher (Interview with convicted poacher 16, 2013) remarked:

You see in a rural area, they [political and traditional leaders] used to call each and everyone that stayed there, and they talked with us to decide about things that concerned us. Now things are different. And they [the government] put the president on the chair. They don't ask us anymore. They do things on their own. It is them that behave like they are crooks. That's why we end up killing the rhinos.

When asked about poaching motivations, most of the interviewed poachers cited feelings of shame of not being able to provide for their families (and shame of having to do so through illegal means), emasculation, stress, disempowerment and anger (cf. the experience of relative deprivation in Walker and Smith, 2002). It is against this backdrop that rhino kingpins and poachers have emerged as self-styled Robin Hoods, who use rhino poaching for social and economic upward mobility. Says one kingpin based in a Mozambican village community (Interview with kingpin 3, 2013):

We are using rhino horn to free ourselves.

The rhino has become a lucrative scapegoat for the continuing relative deprivation and economic marginalization of village communities. Unlike the slow trickledown linked to community beneficiation initiatives of the state and private operators in and around conservation areas, rhino poaching and the high profits associated with it appear to offer immediate relief. It is important to note that displacement, relocation (whether historical or current) and food insecurity are fuelling the fire by not only providing pathways to poaching but also turning communities against conservation and wild animals. The effects of structural violence and relative deprivation are visible in the village communities where people do not only live on the edge of parks but also on the edge of society when it comes to economic and social justice, and sustainable livelihood initiatives.

\section{Are rhino poachers social bandits? ${ }^{14}$}

The influx of hard cash deriving from rhino horn profits into rural communities has created the perception that villagers benefit equally from rhino poaching, in what has been referred to as the 'Robin Hood effect' (Interviews with KNP officials, 2013). The social banditry associated with Robin Hood captures an important aspect of the asserted identities of poachers and kingpins in the village context. The role, functions and identities of kingpins and poachers are however far more complex, multi-layered and contingent on the geographic context. While many poachers originate from village communities, others join hunting crews from communities elsewhere, even from neighbouring countries. The level of social embeddedness of kingpins and poachers varies and carries structural and 
logistical implications for the flow of rhino horn. Of importance are community perceptions of whether their fortunes and livelihoods are improving.

Although many kingpins have an illustrious criminal past in a range of illegal markets and organized crime, policing or conservation, they portrayed their criminal careers in rhino poaching as legitimate livelihoods throughout the process of data collection. Two charismatic Mozambican kingpins, for example, have constructed their identity around the notion of being 'economic freedom fighters', ${ }^{15}$ who struggle for the economic and environmental rights of their communities. Others have labelled themselves as 'businessmen', 'developers', 'community workers' or 'retired hunters' (Interviews with kingpin 1 and 2, 2013). Legitimation strategies also include the appropriation of job labels from the wildlife industry. Rhino poachers regard themselves as 'professional hunters' or 'hunters' (Interviews with convicted poachers and active poachers, 2013). Rangers are easily swayed to look the other direction or assist with operational intelligence, especially when relatives are involved in hunting crews. In light of the low wages paid to wildlife guardians, it is also not unsurprising that rangers, field scouts and other staff in parks start their own hunting crews, get involved or become informants (so-called 'spotters' who provide information on the location of rhino and anti-poaching units) to supplement their meagre earnings.

Mozambican poachers and kingpins also (quite rightly) pointed out that hunting a wild animal was not a crime in Mozambique. At the time of the initial fieldwork for this project, the Mozambican parliament was indeed in the process of drafting comprehensive wildlife crime legislation. According to Portuguese colonial laws, poaching of wildlife was a minor transgression in Mozambique, obtaining discretionary fines until April 2014, except for the occasional heavy-handed action against villagers suspected of subsistence poaching in national parks (Witter, 2013). The Mozambican parliament passed the Conservation Areas Act in April 2014, which provides for custodial sentences for poaching (Republic of Mozambique, 2013). Poachers also said that the hunting of wild animals was a rite of passage for young boys growing up in rural areas, and boys and men had been hunting in the former Coutada 16 and the KNP for many generations. They referred to the double-edged morality of the state allowing white rich men to hunt rhinos legally ${ }^{16}$ while the black man was guilty of a criminal offence. Similar legitimation strategies are employed in other natural resource-dependent economies elsewhere in the southern African region (see for example Hauck, 1997; Hauck and Sweijd, 1999).

Rhino criminals on both sides of the borders were aware that there was talk of possible trade legalization of rhino horn in South Africa. While some poachers interpreted this as a mixed signal (reifying that poaching should not be regarded as a criminal act), others wanted to become involved in legal supply chains. One kingpin said:

As a person who used to do it, I will love to be part of solution to this problem. I am one of those who wish to farm my own rhinos. If you want to stop this, speak to me. If we can be able to arrest the buyers, then the hunters will lose their business.

Beyond offering to resolve the rhino crisis, kingpins have also laid claims to fulfilling important social welfare, community development and political leadership functions. Rhino horn is instrumental to achieving these overtly altruistic goals in an environment 
where the state has failed or is struggling to deliver public services. The actual representatives of the state and traditional leaders fulfil ceremonial duties in some villages, often heavily subsidized by resident kingpins. The following section shows that many community members are sceptical about the benign role of poachers and kingpins but are often left with no better alternatives.

\section{Debunking the myth of criminalized poaching communities}

Local people benefit largely indirectly from rhino poaching, as there are very few direct hand-outs, other than informal taxes paid to community leaders or political office bearers. Otherwise, community beneficiation is relegated to certain kingpins 'throwing a village party' by slaughtering a few cows, providing traditional beer upon the return of a successful poaching expedition to the KNP or buying rounds of drinks in shebeens ${ }^{17}$ with big wads of cash. Others construct basic roads, water wells, spaza shops ${ }^{18}$ and shebeens, and occasionally a few head of cattle are donated for the benefit of the community (Interviews and focus group, 2013, 2015). Compared to the meagre livelihoods of village communities, kingpins and poachers have purchasing power, allowing them to acquire greater volumes of goods and services, which indirectly benefit community members. Foreign or out-of-town poaching crews may rely on local accommodation, food and logistical assistance from the community. It is, however, incorrect to assume that the entire community is complicit or benefits in equal measure, nor should local people be framed as 'poaching communities'.

A generational gap was detected when it came to poaching motivations with implications for communities. Whereas older poachers (30 years and above) were concerned about family and community well-being, younger poachers displayed individualistic anomic traits of self-realization and accumulation. A teenage poacher cited the adage of 'get rich young or die trying' as the leitmotif and inspiration of younger poachers. Another poacher in his mid-20s related how he was bearing the risk when going on hunting expeditions in the KNP, and thus was not prepared to share his profits with the community (Interview with poacher 15, Massingir, 2013): 'It benefits me, I don't give to the community.' The influx of hard cash into communities has also led to increased alcohol consumption, drug use and prostitution (Interview with community leaders, data from law enforcement sources, 2015). A convicted Mozambican poacher noted (Interview with convicted poacher 2, 2013):

The parents get very angry but there's nothing they can do about it. There's no employment in the area. Our parents worry that rangers will kill us. They do warn us but we don't listen. Sometimes on Fridays and Saturdays, they have community meetings to talk to us about the dangers of poaching.

Interviews and focus groups exposed deep rifts; mothers and wives especially were deeply concerned about the poaching phenomenon, fearing for their sons' or husbands' lives, and the potential loss of a breadwinner should they get killed or arrested. Far from being supportive, they shared how poaching had affected the social fabric of village life, mostly to the detriment of women and children. A few half-built houses in the villages 
are indeed a solemn reminder that some poachers do not return from 'Skukuza'.19 According to South African park officials, close to 200 suspected poachers were shot inside the Park between 2010 and 2014. Mozambican sources believe the number of Mozambicans killed inside the KNP to be at least double. Many others have been imprisoned for rhino crimes in South African correctional centres.

Focus groups with community representatives in the borderlands revealed that the deaths of poaching suspects had led to further alienation and outright antagonism of community members towards South African conservation authorities. Community members recounted that many Mozambican villagers traversed the KNP in search of work or to visit families in South Africa. In the eyes of those interviewed, Kruger game rangers kill fellow villagers on the suspicion that all trespassers are poachers. The increasing securitization of responses to rhino poaching is pitting local people against park authorities, rangers, and rhinos. Moreover, these responses have further exacerbated the sentiment that government and conservation authorities value wild animals more than black rural lives.

Therefore, there are varying levels of beneficiation from poaching profits at grassroots level. The myth of criminalized communities serves the othering rather than the inclusion of communities in solutions. According to Kruger officials (personal communication, 2016), there had been 2500 poaching attempts, involving 7500 poachers with 800 weapons in the KNP during 2015. ${ }^{20}$ Perhaps the poignant question should be: What prevents the more than 2.3 million people residing in village communities and semiurban areas adjacent to the KNP from poaching? In light of the high profits associated with rhino poaching, why isn't everybody and their cousin poaching? Understanding leverage points that would enrol communities in legal rather than illegal economies may well render local people guardians willing to protect wildlife and protected areas. The current arsenal of anti-poaching measures is achieving the opposite result.

\section{Concluding remarks}

As suggested elsewhere (Duffy and St John, 2013; Stiles, 2011), wealth and demand in communities further down the supply chain provide the stimulus for illegal hunting. My research confirms this finding but also suggests that the social setting, the historical context, power relationships and the lack of viable economic alternatives (cf. Dewey et al., this issue) provide an enabling environment for rhino poaching to flourish. The high price of rhino horn in Asian consumer markets has led to the comparatively high disbursements for rhino horn on the supply side, ${ }^{21}$ facilitating the entry of new horn producers (poachers, organized crime, criminal elements within the wildlife industry and in conservation circles).

Emerging scholarship on rhino poaching in southern Africa focuses on socioeconomic drivers of rhino poaching, opportunity structures and the role of organized crime (Eloff and Lemieux, 2014; Koen et al., 2014; Montesh, 2013; Rademeyer, 2016b; Warchol and Johnson, 2011). These factors constitute sufficient drivers of poaching behaviour; however, in-depth interviews with poachers, traffickers and communities suggest a complex set of drivers and environmental conditions. Structural, environmental, political and institutional factors associated with post-colonial state building, the 
conservation paradigm and neoliberal economic policies provide an enabling environment for rhino poaching to flourish. Underpinning current conservation initiatives are archaic and elitist preservation and conservation paradigms that discount the potential for harmonious relationships of local communities and wildlife. In the modern context, protected areas continue to present manifestations of colonial dispossession, apartheid segregation and neoliberal expansion. Conservation areas are seen as symbols of elite interests and wealth, inaccessible to the poor majority. These problematic conservation approaches and paradigms have led to a historical lock-in, where romantic and utopian notions of 'Africa's Wild Eden' continue to undermine the support and buy-in of local communities in wildlife conservation. While attempts have been made to garner community buy-in and provide socio-economic development (beneficiation), those interviewed felt deprived of agency in co-determining projects and initiatives that would have a direct impact on their lives and livelihoods. The historical and socio-political context of past and current displacements from protected areas, and an appreciation of the socioeconomic impacts thereof, further assist in understanding why community members may choose a career in poaching, and why some communities may shield their own against anti-poaching responses. In the eyes of the community, anti-poaching measures signify the social reproduction of historical inequalities, stigmatization and alienation of communities, who, under different circumstances and framing, might be agents of change and disruptors of illegal horn supplies.

Building on Dewey et al. (2016) in this special subsection of the journal, clusters of order have emerged in some communities living in and beyond the LNP, and along the boundary of the KNP. Rhino poachers and kingpins are fulfilling quasi-public functions, frequently sanctioned by actual agents of the state. They can provide certainty to a significant portion of the community, contributing to their economic and social well-being where conservationists, the state and private/public partnerships have failed to achieve tangible benefits and a sense of security for the community. Several of these structural and historical drivers are difficult to reverse. The article highlights leverage points that may sway negative perceptions of protected areas and conservation officials. While poachers and kingpins portray themselves as Robin Hoods, community perceptions diverge on the impact of rhino poaching on social cohesion and community aspirations. Criminal actors have seized an opportunity, which could be undone by engaging with those communities affected by economic and physical displacement, loss of agency and systematic alienation. There is a need to listen to the grievances, hopes and wishes of communities. Acknowledgement of the sins of the past and not repeating them will be crucial.

\section{Acknowledgements}

The author would like to thank Matías Dewey, Clifford Shearing and three anonymous reviewers for their insightful comments on earlier drafts of the article. A special tribute goes to the research participants who took the time to contribute to the research and the field assistants who provided support with translations and transcriptions.

\section{Funding}

This research was funded by the Max Planck Institute for the Study of Societies. 


\section{Notes}

1. The price of rhino horn ranged between US\$25,000 and US\$65,000 per kg during data collection undertaken in Vietnam during 2013/2014.

2. Due to its morally suspect role during the apartheid regime and several setbacks since 1994 (e.g. the Marikana Massacre in 2012), the South African Police Service is struggling with its public image, trust and legitimacy (see for example Hornberger, 2014).

3. Approximately 8394-9594 white rhinos and 343-487 black rhinos were counted in the KNP in 2014 (Ferreira et al., 2014: 1).

4. It has been argued elsewhere that not poverty but demand from wealthier communities further down the supply chain was a key driver of illegal hunting (Duffy and St John, 2013; Stiles, 2011).

5. A follow-up study in the north-western Zambezi region of Namibia looked at the impact of human-wildlife conflict on the valuation of wildlife, and how this might potentially lead to poaching decisions (Kahler and Gore, 2015).

6. Brockington coined the concept of 'fortress conservation', which refers to conservation initiatives with the aim 'to preserve wildlife and their habitat through the forceful exclusion of local people who have traditionally relied on the environment in question for their livelihoods' (Igoe, 2002: 594).

7. While the term 'communities' is employed in this article, it is applied cautiously as communities constitute, by no means, a homogeneous group of people.

8. As one of the main funders behind the establishment of the Peace Park, the Kreditanstalt für Wiederaufbau (KdW) shouldered the cost of resettling the villagers.

9. Soil fertility and harvest yields decrease through continued use of the same piece of land. It also leads to land degeneration and massive erosion, which carries severe environmental impacts. Essentially, this restricted form of land use is not only contributing to less food security but also to the environmental degradation of the land.

10. The role and functions of a rhino kingpin are akin to those of a local crime boss. A kingpin recruits hunters and their support team, organizes hunting rifles and arranges the choreography of illegal hunts. He is also responsible for the local transportation and sale of rhino horn. Note: There were no known female rhino kingpins in South Africa and Mozambique up until the time of writing the article in 2016.

11. The El Niño weather phenomenon is further exacerbating food security, having led to widespread droughts across southern Africa in 2015 and 2016.

12. Massé and Lunstrum (2015) have developed the concept of 'accumulation by securitization' to capture the nexus between conservation-securitization, capital accumulation and dispossession. The researchers discuss the increasing privatization and securitization of responses to rhino poaching, which also includes land grabs.

13. Media outlets coined the term 'service delivery' protest or strike actions in the 2000s. Since 2004, South Africa has been host to a wave of protests across the country. Perhaps better described as a 'rebellion of the poor' (Majavu, 2011), popular protests are triggered, among others, by unhappiness with the slow roll-out of basic municipal services (especially water and sanitation), unequal land distribution in rural and urban areas, top-down approaches to governance and lack of consultation and government corruption (Majavu, 2011).

14. In the book Bandits, Hobsbawm (2010) provides a fascinating historical account of banditry and how social bandits fit into the social order.

15. The Economic Freedom Fighters (EFF) is a splinter party of the ruling African National Congress (ANC) in South Africa. Its policy platform of land reform and wealth redistribution is receiving widespread support. 
16. The Convention on the Trade in Endangered Species of Wild Fauna and Flora permits the trophy hunting of white rhinos and five black rhinos per annum in South Africa if stringent permitting regulations are followed.

17. A shebeen is a pub.

18. A spaza shop is a small neighbourhood grocer.

19. Skukuza is the main rest camp and administrative headquarters of the KNP. When a poacher announces that he is 'going to Skukuza', it indicates that he is preparing for a poaching expedition into the KNP.

20. Some poachers may have entered the Park on several occasions, thus reducing the pool of available poachers. In 2014, 4300 poachers were in the park from a pool of a couple of thousand (cf. Ferreira, 2015).

21. At the time of fieldwork, poachers were paid between US\$500 and US\$12,000 per pair of horns depending on the geography, experience, function within the poaching group and social capital of the illegal huntsmen. Poaching profits from a single hunt exceed the annual income of many South Africans and Mozambican citizens.

\section{References}

Appadurai A (1988) The Social Life of Things: Commodities in Cultural Perspective. Cambridge: Cambridge University Press.

Arets EJMM, et al. (2011) Competing claims on natural resources: Global trends and local case studies. Wageningn UR. Available at: http://edepot.wur.nl/196220

Beall J and Ngonyama M (2009) Indigenous Institutions, Traditional Leaders and Elite Coalitions for Development: The Case of Greater Durban, South Africa. London: London School of Economics Development Studies Institute.

Beinart W (2003) The Rise of Conservation in South Africa: Settlers, Livestock, and the Environment, 1770-1950. Oxford: Oxford University Press.

Bell S, Hampshire K and Topalidou S (2007) The political culture of poaching: A case study from northern Greece. Biodiversity and Conservation 16: 399-418.

Büscher B (2010) Seeking 'telos' in the 'transfrontier'? Neoliberalism and the transcending of community conservation in Southern Africa. Environment and Planning A 42: 644-660.

Carruthers J (1993) 'Police boys' and poachers: Africans, wildlife protection and national parks, the Transvaal 1902 to 1950 . Koedoe 36: 11-22.

Carruthers J (1995) The Kruger National Park: A Social and Political History. Pietermaritzburg: University of Natal.

Cock J and Fig D (2000) From colonial to community based conservation: Environmental justice and the national parks of South Africa. Society in Transition 31:22-35.

Comaroff J and Comaroff JL (2006) Law and disorder in the postcolony: An introduction. In: Comaroff J and Comaroff JL (eds) Law and Disorder in the Postcolony. Chicago: Chicago University Press.

Dewey M, Míguez DP and Saín MF (2016) The strength of collusion: A conceptual framework for interpreting hybrid social orders. Current Sociology. Epub ahead of print 5 August 2016. DOI: $10.1177 / 0011392116661226$

Diale T (2016) R84 million handed over in Kruger Park land restitution claim. Department of Rural Development and Land Reform, Pretoria. Available at: www.ruraldevelopment.gov. za/news-room/news-flash/file/4464

Duffy R (2001) Peace parks: The paradox of globalisation. Geopolitics 6: 1-26.

Duffy R and St John FAV (2013) Poverty, Poaching and Trafficking: What Are the links? Report commissioned by Evidence on Demand: Climate \& Environment Infrastructure, Livelihoods. 
London: SOAS, University of London. Available at: http://dx.doi.org/10.12774/eod_hd059. jun2013.duffy

Eloff C and Lemieux AM (2014) Rhino poaching in Kruger National Park, South Africa: Aligning analysis, technology and prevention. In: Lemieux AM (ed.) Situational Prevention of Poaching. London: Routledge, pp. 18-43.

eNCA (2016) Mozambican villagers moved further away from the border to curb poaching. eNCA, 8 March. Available at: www.enca.com/africa/mozambican-villagers-moved-futher-awayborder-curb-poaching

Fenio KG (2014) Poaching rhino horn in South Africa and Mozambique: Community and expert views from the trenches. US Department of State.

Ferreira S (2015) Rhino poaching interventions. Department of Environmental Affairs. Available at: www.environment.gov.za/sites/default/files/docs/rhino_poaching_interventions.pdf (accessed 30 August 2015).

Ferreira SM et al. (2014) Rhino populations estimates in Kruger National Park. Skukuza, Kruger National Park, SANParks.

Filteau MR (2012) Deterring defiance: 'Don't give a poacher a reason to poach'. Journal of Rural Criminology 1: 236-255.

Fischer A et al. (2013) (De)legitimising hunting: Discourses over the morality of hunting in Europe and Eastern Africa. Land Use Policy 32: 261-270.

Forsyth CJ and Marckese TA (1993) Thrills and skills: A sociological analysis of poaching. Deviant Behavior 14: 157-172.

Foster RJ (2006) Tracking globalization: Commodities and value in motion. In: Tilley C et al. (eds) Handbook of Material Culture. London: Sage, pp. 285-303.

Hauck M (1997) Crime, conservation and community development: Ecological criminology and the case study of abalone poaching. University of Cape Town.

Hauck M and Sweijd NA (1999) A case study of abalone poaching in South Africa and its impact on fisheries management. ICES Journal of Marine Science: Journal du Conseil 56: 1024-1032.

Herbig FJW and Warchol G (2011) South African conservation crime and routine activities theory: A causal nexus. Acta Criminologica 24: 21-38.

Hirschi T (1973) Procedural rules and the study of deviant behavior. Social Problems 21: 159-173.

Hobsbawm E (2010) Bandits. London: Abacus.

Hornberger J (2014) We need a complicit police! SA Crime Quarterly 48: 17-24.

Hübschle A (2016: A Game of Horns: Transnational Flows of Rhino Horn. Cologne: International Max Planck Research School on the Social and Political Constitution of the Economy. Available at: http://pubman.mpdl.mpg.de/pubman/item/escidoc:2218357:9/component/ escidoc:2262615/2016_IMPRSDiss_Huebschle.pdf

Igoe J (2002) Review of 'fortress conservation'. The International Journal of African Historical Studies 35: 594-596.

Kahler JS and Gore ML (2012) Beyond the cooking pot and pocket book: Factors influencing noncompliance with wildlife poaching rules. International Journal of Comparative and Applied Criminal Justice 36: 103-120.

Kahler JS and Gore ML (2015) Local perceptions of risk associated with poaching of wildlife implicated in human-wildlife conflicts in Namibia. Biological Conservation 189: 49-58.

Koen $\mathrm{H}$ et al. (2014) A Framework for Inferring Predictive Distributions of Rhino Poaching Events Through Causal Modelling. Pretoria: Council for Scientific and Industrial Research.

Kruger National Park (2015) Great Limpopo Transfrontier Park. Available at: www.krugerpark. co.za/great-limpopo-transfrontier-park-south-africa.html 
Lunstrum E (2010) Reconstructing history, grounding claims to space: History, memory, and displacement in the Great Limpopo Transfrontier Park. South African Geographical Journal 92: 129-143.

Lunstrum E (2013) Articulated sovereignty: Extending Mozambican state power through the Great Limpopo Transfrontier Park. Political Geography 36: 1-11.

Lunstrum E (2015) Green grabs, land grabs and the spatiality of displacement: Eviction from Mozambique's Limpopo National Park. Area 48: 142-152.

Majavu M (2011) Making Sense of Municipal Revolt: Empowering Communities to Effectively Participate in Local Developmental Processes. Cape Town: Foundation for Contemporary Research.

Mamdani M (1996) Citizen and Subject. Princeton Studies in Culture/Power/History. Princeton, NJ: Princeton University Press.

Massé F (2016) The political ecology of human-wildlife conflict: Producing wilderness, insecurity, and displacement in the Limpopo National Park. Conservation and Society 14: 100-111.

Massé F and Lunstrum E (2015) Accumulation by securitization: Commercial poaching, neoliberal conservation, and the creation of new wildlife frontiers. Geoforum 69: 227-237.

Merton RK (1938) Social structure and anomie. American Sociological Review 3: 672-682. Available at: www.jstor.org/stable/2084686

Meskell L (2012) The Nature of Heritage: The New South Africa. Oxford: Wiley-Blackwell.

Milgroom J and Spierenburg M (2008) Induced volition: Resettlement from the Limpopo National Park, Mozambique. Journal of Contemporary African Studies 26: 435-448.

Milliken T (2014) Illegal trade in ivory and rhino horn: An assessment report to improve law enforcement under the Wildlife TRAPS Project. USAID and TRAFFIC.

Molewa E (2016) Minister Edna Molewa highlights progress in the fight against rhino poaching. 21 January. Department of Environmental Affairs, Pretoria.

Montesh M (2013) Rhino poaching: A new form of organised crime. UNISA. Available at: www. unisa.ac.za/claw/news/wp-content/uploads/2013/04/rhion-poaching-for-profit.pdf (accessed 20 May 2014).

Munthali SM (2007) Transfrontier conservation areas: Integrating biodiversity and poverty alleviation in Southern Africa. Natural Resources Forum 31: 51-60.

Muth RM and Bowe JF (1998) Illegal harvest of renewable natural resources in North America: Toward a typology of the motivations for poaching. Society and Natural Resources 11: 9-24.

Neumann RP (2004) Moral and discursive geographies in the war for biodiversity in Africa. Political Geography 23: 813-837.

Ntonzima L and Bayat MS (2012) The role of traditional leaders in South Africa: A relic of the past, or a contemporary reality? Arabian Journal of Business and Management Review (OMAN Chapter) 1: 88-108.

Peace Parks Foundation (2014) Background. Available at: www.peaceparks.org/tfca. php?pid $=19 \& \mathrm{mid}=1005$

Rademeyer J (2012) Killing for Profit: Exposing the Illegal Rhino Horn Trade. Cape Town: Zebra Press.

Rademeyer J (2016a) Beyond Borders: Crime, Conservation and Criminal Networks in the Illicit Rhino Horn Trade. Geneva: Global Initiative against Transnational Organized Crime.

Rademeyer J (2016b) Tipping Point: Transnational Organized Crime and the 'War' on Poaching. Geneva: Global Initiative against Transnational Organized Crime.

Ramutsindela M (2006) Parks and People in Postcolonial Societies: Experiences in Southern Africa. New York: Kluwer Academic Publishers.

Ramutsindela M (2007) Transfrontier Conservation in Africa: At the Confluence of Capital, Politics and Nature. Wallingford: CABI Books. 
Republic of Mozambique (2013) Conservations Areas Act. Assembly of the Republic. Maputo.

SANParks (2012) Revised zoning system - Kruger National Park. 9 July. Available at: www.sanparks.org/parks/kruger/news.php?id=55218?PHPSESSID=p3dhcmvdsgj1 fohog0q0dkeer7

Singh J and van Houtum H (2002) Post-colonial nature conservation in Southern Africa: Same emperors, new clothes? GeoJournal 58: 253-263.

Spierenburg M (2011) The politics of the liminal and the liminoid in transfrontier conservation in southern Africa. Anthropology Southern Africa 34: 81-88.

Spierenburg M (2013) 'We agreed to move, but we did not do so freely'. Resettlement from the Limpopo National Park, Mozambique. Worlds of Human Rights: The Ambiguities of Rights Claiming in Africa 26: 101-128.

Spierenburg M and Wels H (2006) 'Securing space': Mapping and fencing in transfrontier conservation in Southern Africa. Space and Culture 9: 294-312.

Spierenburg M, Steenkamp C and Wels H (2006) Enclosing the local for the Global Commons: Community land rights in the Great Limpopo Transfrontier Conservation Area. Conservation and Society 6: 87-97.

Stark R (1987) Deviant places: A theory of the ecology of crime. Criminology 25: 893-910.

Stiles D (2011) Elephant Meat Trade in Central Africa. Gland, Switzerland: IUCN Species Survival Commission.

Survival International (2016) Botswana: Helicopter crashes after shooting at Bushmen. London.

Tanner C (2002) Law-making in an African context: The 1997 Mozambican Land Law. FAO. Available at: www.fao.org/fileadmin/user_upload/legal/docs/lpo26.pdf

von Essen E et al. (2014) Deconstructing the poaching phenomenon: A review of typologies for understanding illegal hunting. British Journal of Criminology 54: 632-651.

Walker I and Smith HM (2002) Relative Deprivation: Specification, Development, and Integration. Cambridge: Cambridge University Press.

Warchol G and Johnson B (2011) Securing national resources from theft: An exploratory theoretical analysis. Journal of Applied Security Research 6: 273-300.

West's Encyclopedia of American Law (2008) Poaching. West's Encyclopedia of American Law, 2nd edn. The Gale Group. Available at: http://legal-dictionary.thefreedictionary.com/ Poaching

Witter R (2013) Elephant-induced displacement and the power of choice: Moral narratives about resettlement in Mozambique's Limpopo National Park. Conservation and Society 11: 406-419.

\section{Author biography}

Annette Hübschle is a postdoctoral researcher at the Environmental Security Observatory (ESO) at the University of Cape Town (UCT). The ESO is a joint research initiative of the Centre of Criminology, the Global Risk Governance Programme, both located at UCT, and the Global Initiative against Transnational Organized Crime in Geneva. Annette holds a PhD in Sociology from the University of Cologne and a Master's in Criminology from the University of Cape Town. Her research centres on the governance of safety and security with a specific focus on illegal wildlife economies; as well as illegal markets, economic sociology, organized crime and qualitative research methods. Before joining UCT, Annette was a doctoral researcher in the Illegal Markets research group at the Max Planck Institute for the Study of Societies in Germany. In the past, Annette worked as a senior researcher for the former Cape Town office of the Institute for Security Studies, a pan-African applied policy institute. She led and conducted research into organized crime and terrorism in Africa. Annette has worked as a researcher, consultant and practitioner on a variety of organized crime, environmental security and broader African security issues. She also acts as a senior research advisor to the Global Initiative against Transnational Organized Crime. 


\section{Résumé}

En raison de l'incidence élevée des actes de braconnage de rhinocéros en Afrique australe, la population de cet animal à l'état sauvage pourrait disparaître dans un avenir proche. Des chercheurs de diverses disciplines se sont penchés sur les causes de cette chasse illégale et les comportements des braconniers en général. Les travaux consacrés au braconnage des rhinocéros supposent l'existence simultanée de plusieurs facteurs, notamment de l'arrivée d'une criminalité organisée transnationale liée aux espèces sauvages et de la pauvreté endémique des populations vivant à proximité des aires protégées. En s'appuyant sur les expériences vécues et les univers sociaux des braconniers et des populations rurales locales, cet article examine les données empiriques recueillies lors d'un travail de terrain ethnographique avec les braconniers, les prisonniers et les populations locales vivant à proximité du parc national Kruger. II suggère que les contextes sociopolitique et historique, ainsi que l'exclusion persistante des populations locales, constituent des facteurs importants qui influencent les décisions de braconnage au niveau local. L'accaparement des surfaces fourragères et l'exclusion systématique des populations proches des aires protégées, ainsi que le renforcement des mesures sécuritaires visant à prévenir le braconnage induisent les populations rurales noires à penser que la vie des animaux est plus valorisée que la leur. En conséquence, les conservateurs et les représentants de la loi font l'objet de mépris et éprouvent des difficultés à obtenir la coopération de ces populations. Cet article critique le paradigme actuel de la forteresse assiégée de la conservation, qui suppose une relation conflictuelle entre les populations locales et la faune.

\section{Mots-clés}

Braconnage des rhinocéros, chasse illégale, causes du braconnage, lutte contre le braconnage, accaparement des surfaces fourragères, aires protégées, mesures sécuritaires, populations locales, forteresse assiégée de la conservation

\section{Resumen}

Considerando la elevada incidencia de la caza furtiva de rinocerontes en África meridional, los rinocerontes africanos podrían extinguirse de la vida silvestre en un futuro próximo. Los estudiosos de diversas disciplinas han analizado los choferes de la caza ilegal y los comportamiento de la caza furtiva en términos generales. La bibliografía existente sobre la caza furtiva de rinocerontes ofrece una concurrencia simplista de los choferes interrelacionados, incluyendo la entrada de la delincuencia organizada transnacional en el crimen de la fauna, las estructuras de oportunidades y la pobreza endémica que enfrentan las personas que viven cerca de las áreas protegidas. Al comprometerse con las experiencias de vida y mundos sociales de los cazadores furtivos y las comunidades rurales, este artículo refleja en datos empíricos recogidos durante el trabajo de campo etnográfico con los cazadores furtivos, los presos y las personas locales que viven cerca del Parque Nacional Kruger. Se argumenta que el contexto socio-político e histórico y la continua marginación de la población local son factores importantes que facilitan la caza furtiva al nivel de base. El acaparamiento de tierras verdes y la exclusión sistemática de la 
población local de las áreas protegidas, así como la crecientes respuestas seguridad contra la caza furtiva, están ayudando a la percepción de que el animal salvaje se valora más que la vida de los pobladores rurales negros. Como consecuencia, los conservadores y los agentes de la ley son vistos con desdén y se esfuerzan por obtener la cooperación. El artículo critica el paradigma actual de conservación, que supone relaciones de conflicto cargado entre la población local y la vida silvestre.

\section{Palabras clave}

Caza furtiva de rinocerontes, caza ilegal, choferes de la caza furtiva, anti caza furtiva, apropiación de tierras verdes, áreas protegidas, seguridad, comunidades locales, conservación de la fortaleza 